\title{
UN acknowledges HIV/AIDS as a threat to world peace
}

The HIV/AIDS epidemic in sub-Saharan Africa monopolized the agenda when the United Nations (UN) Security Council convened on 10 January, making it the first time in the Council's more than 50-year history that it has addressed a health issue as a threat to a world stability.

The Security Council is charged with the surveillance of international peace and security, and traditionally rules on situations of armed conflict within its member countries. However, speakers at last month's meeting stressed that the HIV/AIDS epidemic is at such proportions in many African countries that it poses a threat to economic, social and political stability.

Opening the meeting, US

Vice President Al Gore-who

attracted adverse publicity

last year over his clashes with

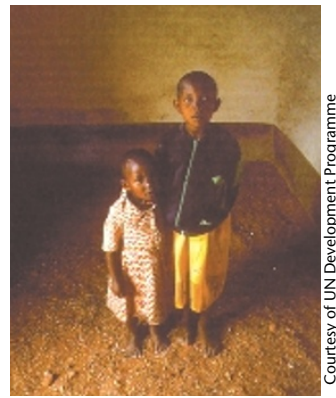

AIDS orphans on the grave of their parents inside their home. AIDS activists on the issue of African access to antiviral drugs (Nature 399, 717; 1999) - announced that the US administration will seek an additional $\$ 100$ million in funding for AIDS prevention and treatment and a further $\$ 50$ million for vaccine research from Congress.

Gore described AIDS as one of the "new pandemics," which along with environmental degradation and the increased use of addictive drugs are as much of a threat to world peace in the $21^{\text {st }}$ century as war and terrorism have been in the past. Whereas conflicts in Africa killed 200,000 people in 1998, HIV/AIDS killed more than 2.2 million in the same year. AIDS is now the leading killer in sub-Saharan Africa-23.3 million people are infected, and the region is home to $90 \%$ of the world's AIDS orphans.

In his speech, Secretary General of the UN Kofi Annan told delegates that over the past year, African governments, private organizations and UN bodies have formed a new international Partnership Against AIDS in Africa, which met at UN headquarters in December. He has asked this group to formulate a response to the crisis by May.

Peter Piot, executive director of UNAIDS, acknowledged that African countries with strong political leadership and openness about AIDS, such as Uganda and Senegal, had managed to reduce infection rate substantially. He criticized international expenditure on AIDS, which was "only" $\$ 167$ million in 1997, and said that to sustain and expand the success stories of Uganda and Senegal, "we need to mobilize between $\$ 1$ billion and $\$ 3$ billion a year."

Mark Malloch Brown, administrator of the UN Development Programme, concluded that HIV/AIDS is "reducing future national GDP size in [Africa] by a third over the next 20 years." He praised those African countries that have made progress-in Uganda, he said, "there is now a real prospect of an almost AIDS-free generation of high-school-age children."

The high-level meeting flies in the face of statements made days earlier by South African President Thabo Mbeki to American news group $C N N$, during which he criticized the West for ignoring Africa's disease problems, and accused the UN Security

Council of being reluctant to intervene in the issue. Mbeki's attack also ignored the December Partnership meeting in New York, which his own health minister, Manto Tshabalala-Msimang, attended. Several South African AIDS experts interviewed by Nature Medicine believe that although the rest of the world is in a panic about the HIV situation in sub-Saharan Africa, their own government shows no genuine concern.

South Africa is the most developed African nation in terms of healthcare infrastructure and services, but the prevalence of HIV in the country's adults is rising rapidly. Moreover, in the absence of intervention, the number of infected children in South Africa will rise from 35,000 per

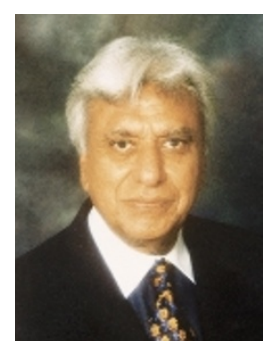

Jerry Coovadia doesn't. So why should we continue?"

How best to persuade the government to take action on the issue of vertical transmission is a current subject of debate among scientists and health experts, and is likely to be one of the hottest issues at July's World AIDS Conference in Durban.

Speaking of the serial excuses given by his government for not advocating AZT use in pregnant women, Salim Karim, head of AIDS research for the Medical Research Council (MRC), wants conference delegates to present a "systematic and scientific erosion of the government's beliefs that AZT is toxic," (Nature 402, 3; 1999).

But although he hopes that an imminent report on the safety of AZT by the country's Medicine's Control Council will be objective and "come up with something solid," Karim is doubtful that the government will backtrack on its AZT policy. He also doubts that Tshabalala-Msimang will advocate nevirapine as a face-saving alternative following her negative attitude to recent trial results from Uganda (Nature Med. 5, 963; 1999).

The most vocal health expert on the issue is Costa Gazi, secretary for health of the Pan-African Congress, who supports a boycott of the AIDS Conference. Last month, Gazi was cleared of 10 of 11 charges of bringing a superior into disrepute after threatening to take the former health minister, Nkosazana DlaminiZuma, to court for culpable homicide for her refusal to make AZT available to pregnant women. Gazi also put the issue before the South African Human Rights Commission, and told Nature Medicine that there could be a chance, based on Tshabalala-Msimang's 15page reply to his charges that she is violating human rights of pregnant women and their offspring, that the govern2008. "Did we fight so hard against apartheid to lose a generation of black children to AIDS?" asks Professor Brian Williams, who runs an HIV prevention program in Carltonville, a mining town outside Johannesburg.

Williams is one of several researchers becoming exasperated with the government's policies, as AIDS researcher Mark Lurie enunciates: "It's extremely frustrating as a scientist to do research and hope it gets integrated into national policy. It ment will introduce nevirapine ahead of the AIDS Conference.

Conference Chair Jerry Coovadia, professor of pediatrics and child health at the University of Natal, has been appealing to potential delegates not to boycott the meeting. He says that years of experience with many of the high-ranking government officials involved have taught him that they become more obdurate when their hand is forced.

Karen Birmingham, London 